\title{
Integration of SMART board technology and effective teaching
}

\author{
Kathryn Min \\ Christine Siegel \\ Fairfield University, csiegel@fairfield.edu
}

Follow this and additional works at: https://digitalcommons.fairfield.edu/education-facultypubs Copyright 2011 imanager Publications Archived with permission from copyright holder.

\section{Peer Reviewed}

\section{Repository Citation}

Min, Kathryn and Siegel, Christine, "Integration of SMART board technology and effective teaching" (2011). GSEAP Faculty Publications. 54.

https://digitalcommons.fairfield.edu/education-facultypubs/54

\section{Published Citation}

Min, Kathryn., \& Siegel, Christine. (2011). Integration of SMART board technology and effective teaching. imanager's Journal on School Educational Technology, 7(1), 38-47.

This item has been accepted for inclusion in DigitalCommons@Fairfield by an authorized administrator of DigitalCommons@Fairfield. It is brought to you by DigitalCommons@Fairfield with permission from the rightsholder(s) and is protected by copyright and/or related rights. You are free to use this item in any way that is permitted by the copyright and related rights legislation that applies to your use. For other uses, you need to obtain permission from the rights-holder(s) directly, unless additional rights are indicated by a Creative Commons license in the record and/or on the work itself. For more information, please contact digitalcommons@fairfield.edu. 


\title{
INTEGRATION OF SMART BOARD TECHNOLOGY AND EFFECTIVE TEACHING
}

\author{
By \\ KATHRYN MIN * \\ * Graduate of Fairfield University in Fairfield, Connecticut. \\ ** Associate Dean \& an Associate Professor, Graduate School of Education and Allied Professions, Fairfield University, Fairfield, Connecticut.
}

\begin{abstract}
The proposed paper reports on the results of a study conducted to explore the influence of SMART Board technology on student engagement in and perception of classroom activities. Using momentary time-sampling procedures, this study examined differences in second grade students' on-task and off-task behaviors during 30-minute math and science lessons that did and did not include the use of a SMART Board. Student perceptions were measured via questionnaire. Observation results revealed that (a) effective teaching, without technology, can promote above-average levels of student engagement, (b) the integration of SMART Board technology can further increase on-task behavior, and (c) the combination of effective teaching and SMART Board technology can maintain high levels of student engagement throughout a multi-component lesson. Questionnaire results provided modest support for the use of the SMART Board to engage students. While none of the participants favored lessons without the SMART Board, only half rated their attention and participation higher in classes that included the SMART Board compared to those that did not. Further research is needed to determine if the integration of SMART Board technology and effective teaching enhances the engagement of students atother grade levels, of other demographic backgrounds, and in other subjectareas.
\end{abstract}

Keywords: StudentEngagement, Effective Teaching, SmartBoard Technology, NetGeneration, Early Elementary Learning.

\section{INTRODUCTION}

The Net Generation, those individuals born between the early 1990s and early 2000s, is the first generation born into the digital revolution which includes the pervasive use of the internet, cell phones, e-mail, video games and social networking tools (Jukes, 2008; Prensky, 2001; Sheets, 1991). These individuals comprise $30 \%$ of the population in the United States and are quickly surpassing the baby boomer generation as the largest age-group in the country (Sheets, 1991, Tapscott, 1998). According to Small and Vorgan (2008), today's children are digital natives in a technologically supercharged world; whereas their parents are digital immigrants. Since the digital revolution is now the mainstay in society, these authors encourage parents to embrace their children's digital culture in order to facilitate their growth as learners and future leaders. This advice is also highly germane to educators who may be designated as digital immigrants along with parents. Schools and teachers need to consider how to integrate technology into the learning environment to promote the academic success of the Net Generation. To this end, the current study explored the use of SMART Board technology in a second grade classroom.

\section{Student Engagement}

The relationship between student engagement and learning has received significant attention in the last two decades coinciding with the evolution of the Net Generation. Student engagement, defined as student commitment to and investment in learning, has been identified as potentially the most significant factor in the learning process (Beeland, 2002; Glanville \& Wildhagen, 2007; Marks, 2000; Painter, Whiting \& Wolters, 2005; Smith, Hardman \& Higgins, 2006). In the classroom, students who are engaged exhibit on-task behaviors that may include answering questions, contributing to class discussions, following directions, or making eye-contact. In contrast, disengaged learners exhibit off-task behaviors such as playing, looking down at the ground, and talking to, looking 


\section{RESEARCH PAPERS}

at, hitting, touching or otherwise distracting other students. These students are often disaffected and passive learners who are at-risk for school failure and drop-out (Glanville \& Wildhagen, 2007; Harris, 2008). Essentially, engaged learners are optimal learners, whereas disengaged learners are often impeded by barriers to learning (Beeland, 2002).

Effective teachers can and do influence student engagement (i.e., on-task behavior) in the classroom. Learning theorists suggest activities that (i) encourage constructive thinking (Piaget, 1972; Sigel \& Cocking, 1977), (ii) address a range of intelligences (Gardner, 1983, 1993, 1999), (iii) are novel and varied (Langer, 1997, 2000), and (iv) allow students to interact and learn from each other (Singer \& Revenson, 1996) promote student engagement. For purposes of this paper, the authors define effective teaching as the use of instructional strategies that address these suggestions and elicits student engagement in the classroom. Examples of such strategies include the use of hands-on science experiments, manipulative materials, puzzles and games, peer sharing, group projects, and small and large group discussions (Bowen, 2007; Marzano, 2007).

\section{Engaging the Net Generation}

In has been argued that the impact of technology on the Net Generation has influenced the ways in which today's children process information and engage in learning (Prensky, 2001: Small \& Vorgan, 2008). Proponents of this view maintain that children's neural circuitry has evolved to adapt to the incessant, fast paced, digital bombardment of their daily environments (Jukes, 2008; Prensky, 2001). Subsequently, the Net Generation may possess unique learning needs. Notably, compared to previous generations, today's children may require more instantaneous feedback and gratification from environments in order to maintain engagement in learning activities (Jukes, 2008; Prensky, 2001).

Acknowledgement of these learning characteristics poses questions about the ability of the current educational system to aptly address the needs of the Net Generation, including, "Is traditional instruction capable of engaging today's students or is a more stimulating format required?"
The designation digital immigrants implies that some adults, including educators who teach without technology, may lack the methods to reach this generation.

Indeed, the use of interactive technology in the classroom, such as the SMART Board, has been encouraged by the No Child Left Behind Act (2002) and is esteemed by researchers to address the learning needs of the Net Generation. According to its proponents, such technology allows teachers and students to interact in novel ways that increase student participation in the classroom (StokesJones, 2010). The majority of interactive white board studies (typically conducted in schools in the United Kingdom, United States, and Australia), report a significant increase in student excitement and engagement with the technology (Becta, 2006; Beeland, 2002). Stokes-Jones (2010) asserted that the "interactive white board increased student motivation, engagement, and interaction..." (p.2). Additional studies report that the use of interactive white boards increased student achievement as well (Marzano, 2009).

\section{Unanswered Questions}

Given the studies heralding technology's acclaim, it is pertinent to consider if technology alone is enough to address students' needs. Indeed, the emphasis on technology and de-emphasis on teacher skill in this literature may lead to the false representation that the roles of teachers are secondary to that of technology. To the contrary, other studies illustrate the impact of an effective teacher on student engagement that is independent of other variables in the school setting (Marzano, 2007). If effective teaching without technology can adequately engage children, then what role does technology play in enhancing student engagement? The research and blogging communities are beginning to explore the idea that a balance of effective teaching methods and technology can best engage the Net Generation of learners. With this in mind, the current study explored the assertion that the integration of SMART Board technology can serve to enhance student engagement in classrooms where effective (i.e., engaging) teaching methods are present.

\section{Research Questions}

- Does the integration of SMART Board technology with effective teaching methods enhance student 
engagement? If so, for which components of a lesson does technology increase engagement?

- What are students' perceptions of lessons that include or exclude the SMART Board technology?

Method

\section{Context}

School

The study was conducted in a Connecticut elementary school comprised of approximately 450 students in prekindergarten through fifth grade. The site served as the year-long internship placement for the primary author. The student population was predominantly Caucasian and the majority resided in middle to upper-middle class suburban neighborhoods. Technology resources at the school included networked computers in each classroom (with podcast, Web, and Skype), a computer lab, and SMART Board technology in the media center which also housed networked computers, laptops, printers, CDs, and DVD players. Additionally, SMART Board technology was implemented into classrooms on a voluntary basis during the year in which the study was conducted, and is under consideration for integration in all classrooms in the future.

Teacher

Teachers who volunteered received basic training in the use, mechanics and set up of the SMART Board and were provided autonomy on how to utilize it in their classrooms. The teacher for the present study was selected on the basis of consistent use of the SMART Board in the classroom across a variety of subjects.

\section{Classroom}

The study was conducted in a second-grade general education classroom. Desks were arranged in groups of four or five toward the back of the room. In the front of the room, a rug was placed in front of a flip chart and the SMART Board. During instruction, the teacher was positioned to the right of the SMART Board of flip chart, facing the students.

\section{Participants}

Eighteen students, nine boys and nine girls, comprised the class, which was half of the entire second grade population. Students are assigned to classes by the building administer with consideration to relative balance of boys and girls and total number of students in the classroom. Prior to the study, participants had exposure to the SMART Board technology in the majority of subjects, with the exception of science. Passive, informed consent for participation was obtained from the students' parents or legal guardians.

\section{Materials}

For purposes of this study, SMART Board technology was used by the participating teacher during math and science lessons. The SMART Board is an interactive display that projects a computer's desktop image onto a touchsensitive white-board surface that allows students to manipulate the projected images with their fingers. For example, during a geometry lesson, shapes were projected on to the interactive surface. Students were asked to form a trapezoid using the available shapes. A student volunteer selected a rhombus and a triangle with her finger. She then used her finger to slide the shapes and superimpose them on the trapezoid. The shape illuminated to indicate a correct answer. The student used the SMART pen to write the names of the shapes used.

\section{Classroom Observations}

The primary investigator conducted 12 classroom observations over two consecutive weeks. During week 1 , students were observed during three math and three science lessons that excluded the SMART Board. During week 2, students were observed during three math and three science lessons that included the SMART Board. As

\begin{tabular}{|c|c|c|}
\hline $\begin{array}{l}\text { Approximate } \\
\text { Time (minutes) }\end{array}$ & $\begin{array}{l}\text { Instructional } \\
\text { Component }\end{array}$ & Description \\
\hline 10 & $\begin{array}{c}\text { Didactic } \\
\text { Instruction }\end{array}$ & $\begin{array}{l}\text { Presentation of new or a review of previous } \\
\text { concepts either with or without the SMART Board. } \\
\text { The teacher used flip charts or a book to aid } \\
\text { instruction during lessons without the SMART Board }\end{array}$ \\
\hline 2 & $\begin{array}{l}\text { Pairing \& } \\
\text { Sharing }\end{array}$ & $\begin{array}{l}\text { Questions posed to students about concepts. } \\
\text { Teacher asked students to turn to a partner and share } \\
\text { their answers with the student, and then with the class. } \\
\text { TheSMART Board was not used with this component }\end{array}$ \\
\hline 15 & Activity & $\begin{array}{l}\text { Activities designed to reinforce concepts presented. } \\
\text { Occurred in groups, on the rug, at seats, inside or } \\
\text { outside the school and included the use of } \\
\text { manipulatives, group work, hands on experiments, } \\
\text { and scavenger hunts. The SMART Board was not used } \\
\text { with thiscomponent }\end{array}$ \\
\hline 3 & Discussion & $\begin{array}{l}\text { Questions posed to students to describe findings } \\
\text { from the activity and relate to lesson concepts. } \\
\text { Discussions included or excluded the SMART Board }\end{array}$ \\
\hline
\end{tabular}




\section{RESEARCH PAPERS}

illustrated in Table 1, all lessons were approximately 30 minutes and included four instructional components: Didactic Instruction, Pairing \& Sharing, Activity, and Discussion. The teacher developed lessons and choose to include the SMART Board during the Didactic and Discussion components.

\section{Week 1}

During the first week, Didactic Instruction consisted of the teacher presenting new or previously learned concepts in geometry or states of matter via lecture accompanied by drawings on the flip chart or in a book. During Pairing \& Sharing students turned to each other and responded to a question raised by the teacher, and then shared their responses with the class. The students then participated in the Activity component that included small group activities such as fact finding, drawing, experiments, scavenger hunts and use of manipulatives on the rug or at their desks. Week 1 lessons concluded with Discussion where students were encouraged to share their experience from the Activity.

\section{Week 2}

Lessons during week 2 followed the same format as those in week 1. Week 2 lessons however, incorporated the SMART Board during the Didactic Instruction in lieu of flip chart and books, and during Discussion to supplement student commentary. The SMART Board was not used during the Pairing \& Sharing and Activity components during week 2.

\section{Measures}

\section{Student Behaviors}

Students' task-related behavior was measured using momentary time-sampling procedures. The 30-minute lessons were divided into 180, ten-second intervals for recording. At the beginning of each ten-second interval, the behavior of one student was observed and recorded as either on-task (+) or off-task (-). On-task behavior was defined as the student raising his/her hand, answering questions, writing when appropriate, contributing to topic discussions, following directions, asking relevant questions, making eye-contact with the teacher or a contributing student, or looking at the flip chart or SMART Board. Off-task behavior was defined as the student looking around the room, at another student or down at the floor, writing or drawing when not appropriate, playing, talking to other students when not appropriate, hitting, touching, distracting other students, and getting out of his/her seat without permission. At the beginning of the next 10-second interval, another student's behavior was observed and recorded such that each student was observed 10 times during a lesson. Students were assigned seating in rows for better tracking and to ensure that all were observed for an equal number of intervals.

\section{Student Perceptions}

A questionnaire, developed for purposes of this study, was used to assess student perceptions of their learning with and without the SMART Board. Questions were designed to assess the student's preferences, perceived level of participation, attention, understanding and fun during both lesson formats. Response options included (i) yes, (ii) no, and (iii) both are the same. Questionnaires were administered by the classroom teacher at the end of the two-week observation period. Mindful of the developmental level of second graders, the questionnaire included the following four questions.

- When the teacher uses the SMART Board, the class is more fun than when the teacher does not use it.

- When the teacher uses the SMART Board, I get to participate more than when the teacher does not use it.

- When the teacher uses the SMART Board, I understand more than when the teacher does not use it.

- When the teacher uses the SMART Board, I pay more attention than when the teacher does not use it.

Analysis

\section{Student Engagement by Lesson}

In order to determine the level of student engagement during lessons, the percent of intervals marked as on-task $($ i.e., + ) for each of the 12 observations was determined. For example, in the third math lesson of week 1, 129 of the 180 intervals, or $72 \%$, were designated as on-task. Next, the average percents of on-task intervals for lessons by subject and inclusion or exclusion of the SMART Board were determined. For example, the percent of on-task intervals for the three math lessons during week 1 that excluded the SMART Board were summed and divided by three (Tables 2 and 3 ).

Student Engagement by Instructional Component 
The average percent of intervals of on-task behavior for each instructional component within each of the 12 lessons by subject was then determined (Tables 4 and 5). For example, Didactic Instruction, which occurred for approximately 10 minutes, contained 60 intervals. During the first math lesson of week 1, 37 of the 60 Didactic Instruction intervals were marked as on-task, for a percent of 62. Pairing \& Sharing occurred for approximately two minutes and contained 12 intervals, Activity occurred for approximately 15 minutes and contained 90 intervals, and Discussion occurred for approximately three minutes and contained 18 intervals.

\section{StudentPerceptions}

Student perceptions were determined based on analysis of questionnaire responses. The average percent for each response (i.e., yes, no, both are the same) to each of the four questions was calculated. The questions were condensed on the upper half of the page and the lower half was left blank. The questionnaire did not elicit comments; however, some students provided comments in the blank space. The percent of students who commented was determined. Student comments were reviewed for content.

\section{Results}

\section{Student Engagement}

Week 1

During the first week, students were observed in lessons that did not include the SMART Board. On average, the students were observed to be on-task for $74 \%$ of the intervals during math lessons and $67 \%$ of the intervals during science

\begin{tabular}{lcc}
\hline \multicolumn{1}{c}{ Lesson } & Week 1: Without SMART Board & Week 2: With SMART Board \\
\hline Math 1 & $79 \%$ & $98 \%$ \\
Math 2 & $71 \%$ & $93 \%$ \\
Math 3 & $72 \%$ & $94 \%$ \\
Mean Math Lessons & $74 \%$ & $95 \%$ \\
\hline
\end{tabular}

Note: Percentages are rounded to whole numbers Table 2. Percent of Intervals of On-task Behavior for Math Lessons by Week

\begin{tabular}{lcc}
\hline \multicolumn{1}{c}{ Lesson } & Week 1: Without SMART Board & Week 2: With SMART Board \\
\hline Science 1 & $65 \%$ & $93 \%$ \\
Science 2 & $68 \%$ & $96 \%$ \\
Science 3 & $67 \%$ & $86 \%$ \\
Mean Science Lessons & $67 \%$ & $92 \%$ \\
\hline
\end{tabular}

Table 3. Percent of Intervals of On-task Behavior for Science Lessons by Week lessons, as depicted in Tables 2 and 3 respectively. While the typical amount of on-task behavior varies, it has been estimated that students generally are on-task $30-40 \%$ of instructional time (Woolfolk, 2004). The current finding illustrates that students in the present study exhibited above average on-task behavior during lessons without technology. The percent of on-task behavior varied for components of the lesson, with the highest levels of on-task behavior occurring during the Pairing \& Sharing and Activity components (Tables 4 and 5). During math lessons without the SMART Board, an average of $81 \%$ of the Pairing \& Sharing intervals and $86 \%$ of the Activity intervals were designated as on-task (Table 4). Similarly, during science lessons without the SMART Board, students were on-task for an average of $78 \%$ of the Pairing \& Sharing and $78 \%$ of the Activity intervals (Table 5). Students were on-task less often during the Didactic Instruction and Discussion components of both math and science lessons without the SMART Board. The average percent of on-task behavior was 58\% during Didactic Instruction and $65 \%$ during Discussion components for math (Table 4). During science lessons, an average of $52 \%$ of the Didactic Instruction intervals and $54 \%$ of the Discussion component intervals were designated as on-task (Table 5).

\section{Week 2}

When the SMART Board was introduced, the students were observed to be on-task for an average of $95 \%$ of the intervals during math lessons and $92 \%$ of the intervals during science lessons (Tables 2 and 3). When compared

\begin{tabular}{ccc}
\hline Instructional Component & $\begin{array}{c}\text { Week 1: } \\
\text { Without SMART Board }\end{array}$ & $\begin{array}{c}\text { Week 2: } \\
\text { With SMART Board }\end{array}$ \\
\hline Didactic Instruction & $58 \%$ & $97 \%$ \\
Pairing \& Sharing & $81 \%$ & $89 \%$ \\
Activity & $86 \%$ & $96 \%$ \\
Discussion & $65 \%$ & $91 \%$ \\
\hline
\end{tabular}

Note: Percentages are rounded to whole numbers

Table 4. Average On-Task Behavior for Instructional Components in Math by Week

\begin{tabular}{ccc}
\hline Instructional Component & $\begin{array}{c}\text { Week 1: } \\
\text { Without SMART Board }\end{array}$ & $\begin{array}{c}\text { Week 2: } \\
\text { With SMART Board }\end{array}$ \\
\hline Didactic Instruction & $52 \%$ & $92 \%$ \\
Pairing \& Sharing & $78 \%$ & $92 \%$ \\
Activity & $78 \%$ & $93 \%$ \\
Discussion & $54 \%$ & $83 \%$ \\
\hline & Note: Percentages are rounded to whole numbers
\end{tabular}

Table 5. Average On-Task Behavior for Instructional Components in Science by Week 


\section{RESEARCH PAPERS}

to week 1, students exhibited a $21 \%$ increase in on-task behavior during math lessons and $25 \%$ increase during science lessons in week 2 (Tables 2 and 3 ). The greatest gains occurred during the Didactic Instruction and Discussion components of the lessons (Tables 4 and 5). Specifically during math lessons, students were on-task for $97 \%$ of the Didactic Instruction intervals that included the SMART Board, an increase of $39 \%$ over the $58 \%$ they exhibited during the Didactic Instruction intervals that did not use the SMART Board (Table 4). Likewise during science lessons, students were on-task for $92 \%$ of the Didactic Instruction intervals that used the SMART Board, an increase of $40 \%$ over the $52 \%$ of Didactic Instruction intervals that did not use the SMART Board (Table 5). Similar gains were noted for the Discussion components of math and science lessons, where the percent of on-task intervals increased by $26 \%$ for math lessons and 29\% for science lessons (Tables 4 and 5).

During the second week, students continued to exhibit above-average levels of on-task behavior during the Pairing \& Sharing and Activity components, with modest gains associated with the SMART Board. In math lessons that incorporated the SMART Board during the Didactic and Discussion components, students demonstrated continued on-task behavior for $89 \%$ of the Pairing \& Sharing and $96 \%$ of the Activity components. These figures represent increases of $8 \%$ and $10 \%$ respectively over week 1 (Table 4). For science lessons that included the SMART Board during Didactic and Discussion components, students demonstrated $14 \%$ increase in on-task behavior during Pairing \& Sharing and a $15 \%$ in the Activity components (Table 5).

\section{StudentPerceptions}

Student responses to the questionnaire illustrated that $67 \%$ had more fun and $83 \%$ understood more during SMART Board lessons. Only 50\% reported that they paid more attention during SMART Board lessons, while the remaining $50 \%$ felt that they paid attention equally during both formats. Responses also indicated that $44 \%$ of students felt they participated more when the SMART Board was used, with $56 \%$ reporting that they participated equally during both formats. Overall, $33 \%$ of the students included voluntary comments that favored the SMART Board, while the remaining $67 \%$ did not include comments.

\section{Discussion}

Today's students were born into and are growing up in a technologically-advanced world. They arrive at school equipped with cell phones, iPods and laptops. They arrange play-dates and outings via text and e-mail, they meet and connect with friends on social networking sites, they have their own personal web-pages and they blog and tweet their way to popularity. In response, educators from preschool teachers to college professors are left to debate how best to engage them in learning. Do we insist that they put down the equipment, disconnect from the digital network and attend to technology-free instruction? The link between effective teaching, student engagement and student achievement is well-established in the educational literature that is replete with examples of engaging instructional methods that do not rely on the use of technology. Or do we meet them in cyberspace by podcasting lectures, supplementing class discussions with the latest YouTube videos, and posting homework assignments on our own web-pages? Can we expect elementary school students to attend to flip-charts, or have they evolved to meet their technology-rich environment such that they require something more? While some may opt for either-or, the results of the current study suggest that the integration of technology with effective teaching may be the approach to enhancing the academic engagement of the NET Generation.

\section{StudentEngagement}

Prior literature demonstrates that the use of technology in the classroom provides learning opportunities that can enhance student engagement and learning (Becta, 2006; Beeland, 2002; Higgins, Beauchamp \& Miller, 2007; StokesJones, 2010). Consistent with these findings, the results of the current study revealed substantial increases in on-task behavior during the Didactic and Discussion components of both math and science lessons when the SMART Board was used.

In consistent with this prior literature, which tends to portray the teacher as an accessory to technology, the current study also demonstrated that technology is not the only 


\section{RESEARCH PAPERS}

way to engage students. During week 1, the Pairing \& Sharing and Activity lesson components were engaging, and elicited above-average on-task behavior without the use of the SMART Board.

New to the debate about the use of technology in the classroom, the results of the current study further demonstrated the SMART Board can enhance student engagement for lessons that are already engaging. During week 1, students in this study demonstrated aboveaverage levels of overall engagement in math and science lessons without the use of technology. These levels rose even higher during week 2 when the SMART Board was used.

It was interesting to note that student engagement increased modestly during the Pairing \& Sharing and Activity components of week 2, even though the SMART Board was not used for these components. One possible explanation for this finding is that the SMART Board served to initiate engagement at a high level during the Didactic component, and that this initiation helped to maintain a high level of engagement during subsequent components, thereby increasing the overall level of engagement for the whole lesson. This finding suggests a beneficial alliance between effective teaching and technology on student engagement. The combination of the use of the SMART Board in the first and last components along with effective teaching methods during the middle of the lesson may have served to provide a mix of (i) novelty and variety, (ii) multisensory stimulation, and (iii) active learning which optimized student engagement.

\section{StudentPerceptions}

Students are the primary recipients of the benefits of SMART Board technology, yet the majority of prior research in this area documents the teachers' or observers' experience with the interactive white board or their perceptions of the students' experience. The current study examined the perceptions of the second graders who participated in the observed lessons.

Overall, the student perceptions provided modest support for the use of SMART Boards. While none of the students favored lessons without technology, only half found the SMART Board to be more engaging (i.e., increasing their attention and participation) than lessons without the SMART Board. One possible explanation for this finding is that while we, digital immigrants, identify the SMART Board as an innovation, the second graders, digital natives growing up immersed in technology, do not recognize it as out of the ordinary. The lack of enthusiasm for the SMART Board among students in the current study may be attributed to the fact that its presence in their classroom is not surprising.

\section{Limitations and Implications for Further Study}

Despite careful planning, limitations of the current study are apparent and worth mentioning for future endeavors. First, the results of the current study may have limited generalizability due to the sample size and use of descriptive statistics. The sample for the current study was small and lacked demographic variability; subsequently, the current results may have limited generalizability to other second grade students. Additionally, because observations were limited to one teacher's second grade math and science classes, the results may not generalize to other teachers, elementary grade levels, or subject areas. Lastly, in some cases, descriptive measures may not infer to other populations. Subsequent research that replicates the current findings across multiple teachers and subjects, with larger samples and increased demographic variation is needed. The use of inferential statistical analysis may also be helpful in the future.

Second, the lack of multiple observers and a control group presents some potential compromises to internal validity. Ideally, observations would have been conducted by multiple observers and inter-rater reliability would have been established. While there was no designated control group, observations of the same group with and without technology allow for appropriate comparisons. Future researchers may want to replicate the studies with multiple observers and multiple intervention groups.

Third, while the current study begins to explore the relationship between technology and student engagement, it did not, however, compare SMART Board use to the use of non technical interactive learning intentions. Additionally, observations were limited to 30minute instructional periods. Further research is needed to explore multiple types of interventions and student 


\section{RESEARCH PAPERS}

engagement over longer periods of time in order to fully understand the ways in which technology can enhance engagement.

Fourth, while previous research suggests achievement gains occur with increased student engagement, the current study did not assess related student achievement for the math and science lessons observed. Specifically, the study did not examine whether increases from above average to high levels of engagement (i.e., on-task behavior) are associated with achievement gains. Future researchers are left to consider whether the increases in engagement observed translate to meaningful differences in academic performance.

Lastly, the results from the current observations and student reports were somewhat inconsistent. While substantial gains in engagement were observed, particularly during the Didactic and Discussion lesson components, student reports of increased engagement were equivocal. One reason for this inconsistency may be weaknesses in the student survey. Clearly, further research into student perceptions is needed. If future researchers use combined method of observations and surveys, they would be well advised to more clearly align the survey to the observational scheme. This strategy may yield more consistent results between the two methods.

Despite the limitations, the current study is a good first step to examine the integration of effective teaching and technology. Results serve to demonstrate that the balance of technology and engaging instruction that is being discussed by bloggers and educators can indeed engage the Net Generation.

\section{References}

[1]. Becta (2006). Interactive whiteboards and primary literacy. Retrieved, August 3, 2010, from http://schools.becta.org.uk/index.php?section=re\&catco $\mathrm{de}=$ fitsprimary_form\&rid $=11899$.

[2]. Beeland, W. D., Jr. (2002). Studentengagement, visual learning and technology: Can interactive whiteboards help? Retrieved, March 10, 2010, from http://chiron.valdosta.edu/are/Artmanscrpt/voll nol/beela nd_am.pdf.
[3]. Bowen, J. A. (2007). Teaching Naked: Why removing technology from your classroom will improve student learning. Retrieved, August 7, 2010, from http://www.ntlf.com/html/ti/naked.htm.

[4]. Gardner, H. (1983). Frames of Mind: The Theory of Multiple Intelligences. New York: Basic Books.

[5]. Gardner, H. (1995). How Are Kids SMART?: Multiple Intelligences in the Classroom. Lanham, MD: Rowman \& Littlefield Publishers, Inc.

[6]. Gardner, H. (1999). Intelligence Reframed: Multiple intelligences For the 21st Century. New York, NY: Basic Books.

[7]. Glanville, J.L. \& Wildhagen, T. (2007). The measurement of school engagement: Assessing dimensionality and measurement invariance across race and ethnicity. Educational and Psychological Measurement, 67, 1019-1041.

[8]. Hall, I. \& Higgins, S. (2005). Primary school students' perceptions of interactive whiteboards. Journal of Computer Assisted Learning, 21, 102-117.

[9]. Harris, L.R. (2008). A phenomenographic investigation of teacher conceptions of student e $\mathrm{ng}$ a g e m e $\mathrm{n} \dagger$ in learning. The Australian Educational Researcher, 35 (1), 57 79.

[10]. Higgins, S., Beauchamp, G., \& Miller, D. (2007). Reviewing the literature on interactive white boards. Learning, Media and Technology, 32 (3), 213-235.

[11]. Jukes, I. (2008). Understanding digital kids: Teaching and learning in the new digital landscape. Retrieved March 10, 2010, from Hp://www.hmleague.org/Digital\%20Kids. pdf. [12]. Langer, E. J. (1997). The Power of Mindful Learning. Reading, MA: Lifelong Books.

[13]. Langer, E. J. (2000). Mindful learning. Current Directions In Psychological Science, 9 (6), 220-223.

[14]. Langer, E.J, \& Moldoveanu, M. (2000). The construct of mindfulness. Journal of Social Issues, 56 (1), 1-9.

[15]. Marks, H.M. (2000). Student engagement in instructional activity: Patterns in the elementary, middle, and high school years. American Educational Research Journal, 37 (1), 153-184. 


\section{RESEARCH PAPERS}

[16]. Marzano, R. (2007). The Art and Science of Teaching: A Comprehensive Framework for Effective Instruction. Alexandria, VA: Association for Supervision \& Curriculum Development.

[17]. Marzano, R. (2009). Evaluation study of the effects of Promethian Activclassroom on student achievement. $\mathrm{R} e+\mathrm{r}$ i e ved $\mathrm{M}$ a y 5, $2010 \mathrm{frOm}$ http://www.prometheanworld.com/upload/pdf/Final_Rep ort_on_ActivClassroom_\%282\%29.pdf

[18]. Means, B. (2010). Technology and education change: Focus on student learning. Journal of Research on Technology in Education, 42(3), 285-307.

[19]. Painter, D. D., Whiting, E., \& Wolters, B. (2005). The use of an interactive whiteboard in promoting in te ractive teaching and learning. VSTE Journal, 19(2), 31-40.

[20]. Piaget, J. (1972). To Understand Is To Invent. New York, NY: The Viking Press, Inc.

[21]. Prensky, M. (2001). Digital natives, digital immigrants. Retrieved March 1, 2010, from http://www. marcprensky.com/writing/Prensky\%20\%20Digital\%20Natives,\%20Digital\%2Olmmigrants\%20$\% 20$ Part1. pdf.

[22]. Sheets, B. H. (1991). Book review of growing up digital: The rise of the Net generation. Information Technology, Learning and Performance Journal, (17) 2, 53-56.

[23]. Sigel, I. and Cocking, R. (1977). Cognitive
Development from Childhood to Adolescence: A Constructivist Perspective. NY: Holt, Rinehart and Winston.

[24]. Singer, D.G., \& Revenson, T.A. (1996). A Piaget Primer: How a Child Thinks; Revised Edition. New York, NY: Penguin Books USA Inc.

[25]. Small, G. \& Vorgan, G. (2008). iBrain: Surviving the Technological Alteration of the Modern Mind. New York, NY: HarperCollins Publishers Inc.

[26]. Smith, F., Hardman, F., Higgins, S. (2006). The impact of interactive whiteboards on teacher-pupil interaction in the national literacy and numeracy strategies. British Educational Research Journal, 32 (3), 437-451.

[27]. Stokes-Jones, T. (2010). Integrating SMART board technology in the elementary classroom. Essentials (7) 1. Retrieved March 20, 2010, from http://extended.emich.edu/uploadedFiles/Template_Ele ments/Publications/Essentials\%20W\%2010.pdf.

[28]. Tapscott, D. (1998). Grown Up Digital: How the Net Generation is Changing Your World. Columbus, $\mathrm{OH}$ : McGraw Hill Companies Inc.

[29]. U.S. Department of Education. (2002). No Child Left Behind Act of 2001. Retrieved March 30, 2010 from http://www2.ed.gov/policy/elsec/leg/esea02/107-1 10.pdf. [30]. Woolfolk, A. (2004). Educational Psychology, Active Learning Edition. Boston, MA: Allyn \& Bacon, Inc. 


\section{RESEARCH PAPERS}

\section{ABOUT THE AUTHORS}

Kathryn Min, NCSP, is a recent graduate of Fairfield University in Fairfield, Connecticut where she received a Master of Arts and a Certificate of Advanced Study in School Psychology. After completing certification as a nationally certified school psychologist, she was awarded a fellowship in the Leadership Education in Neurodevelopmental and Related Disabilities Program at the University of Connecticut Center for Excellence in Developmental Disabilities in Farmington, Connecticut. As part of her fellowship, She interned with a Birth to Three Program based at The Kennedy Center in Trumbull, Connecticut where she provided support to infants and their families throughout Fairfield County. She will pursue a doctoral degree in Clinical Psychology with a focus on child and adolescent psychology beginning in September, 2011 at the University of Hartford in West Hartford, Connecticut.

Christine Siegel, Ph.D. is the Associate Dean and an Associate Professor of the Graduate School of Education and Allied Professions at Fairfield University in Fairfield, Connecticut. She received a BS in Biology and MA in Educational Psychology from Marist College in Poughkeepsie, New York. She attended the State University of New York at Albany where she earned a CAS in School Psychology and a PhD in Educational Psychology and Statistics. Following the completion of her doctoral degree in 1998, She worked as a school psychologist and held adjunct faculty positions at Marist College and Fairleigh Dickinson University. Prior to joining the faculty at Fairfield University in 2005, She was an assistant professor at Georgia State University in Atlanta, Georgia, where she was an active member of the Georgia Association of School Psychologists, and reviewer for the Journal of Educational and Psychological Consultation. Among her varied research interests, She explores the implementation of research or theory-based instructional practices in school settings. 